\title{
Assessment of Quality and Safety of Winged Termites (Macrotermes bellicosus) Enriched Locally Formulated Complementary Foods
}

\author{
Oladejo Thomas Adepoju ${ }^{1} \&$ Kayode Ajayi ${ }^{2}$ \\ ${ }^{1}$ Department of Human Nutrition, Faculty of Public Health, College of Medicine, University of Ibadan, Ibadan, \\ Oyo State, Nigeria \\ ${ }^{2}$ Department of Human Nutrition and Dietetics, Faculty of Basic Medical Sciences, College of Medicine and \\ Health Sciences, Afe Babalola University, Ado-Ekiti, Ekiti State, Nigeria \\ Correspondence: Department of Human Nutrition, Faculty of Public Health, College of Medicine, University of \\ Ibadan, Ibadan, Oyo State, Nigeria. E-mail: tholadejo@yahoo.com
}

Received: June 27, 2017

Accepted: July 30, 2017 Online Published: September 5, 2017

doi:10.5539/jfr.v6n5p117

URL: https://doi.org/10.5539/jfr.v6n5p117

\begin{abstract}
Addition of edible insects to local staples used as complementary foods can improve their nutrient content. Nutritional quality and safety of Macrotermes bellicosus enriched boiled rice (BR) and yam (BY) complementary foods (CFs) was assessed using rats. Macrotermes bellicosus (MB) were collected, dried, and refrigerated at $-4^{\circ} \mathrm{C}$. Ground $\mathrm{MB}$ was added to $\mathrm{BR}$ and $\mathrm{BY}$ in ratios $10.0 \%, 15.0 \%, 20.0 \%(\mathrm{w} / \mathrm{w})$ to give $\mathrm{BR}_{1}, \mathrm{BY}_{1}$; $\mathrm{BR}_{2}, \mathrm{BY}_{2}$, and $\mathrm{BR}_{3}, \mathrm{BY}_{3}$ respectively. Nutrient content of $\mathrm{MB}, \mathrm{BY}, \mathrm{BR}$ and $\mathrm{MB}$-enriched $\mathrm{CF}$ s were determined by AOAC methods. Nutrient bioavailability and safety of $\mathrm{BR} 3$ and $\mathrm{BY}_{3}$ were assessed using rats fed ad libitum for 28 days. Serum trace minerals in the CFs, control and basal diets and histopathological effects of CFs on rats' organs were determined. Data were analysed using ANOVA at $\mathrm{p}<0.05$. Dried MB contained $31.8 \mathrm{~g}$ protein, $16.4 \mathrm{~g}$ fat, $3.8 \mathrm{~g}$ ash, $227.5 \mathrm{mg}$ calcium, $2.1 \mathrm{mg}$ iron, $15.0 \mathrm{mg}$ zinc, $330.4 \mu \mathrm{g}$ retinol equivalent (RE), and $529.0 \mathrm{kcal}$ energy $/ 100 \mathrm{~g}$ sample. The BR and BY contained 3.7-5.9g protein, 70.0-120mg calcium, $4.2-5.6 \mathrm{mg}$ iron, $1.2-1.5 \mathrm{mg}$ zinc and $380-386 \mathrm{kcal} / 100 \mathrm{~g}$ compared with $7.9-15.3 \mathrm{~g}$ protein, $242.2-264 \mathrm{mg}$ calcium, $2.4-4.4 \mathrm{mg}$ iron, $15.1-19.8 \mathrm{mg}$ zinc and $357-372 \mathrm{kcal} / 100 \mathrm{~g}$ enriched CFs $(\mathrm{p}<0.05)$. Rats Serum trace minerals ranged between $3.4-4.3 \mathrm{mg}$ zinc,

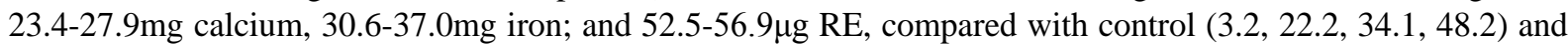
basal $(2.2,21.1,24.0 \mathrm{mg}, 32.3 \mu \mathrm{g})$ diets respectively $(\mathrm{p}<0.05)$. No pathological lesions were observed in internal organs of rats on CF diets. Adding Macrotermes bellicosus to local complementary foods is safe and improved their nutritional quality, hence its use is recommended among mothers.
\end{abstract}

Keywords: Macrotermes bellicosus, complementary foods, nutritional quality, trace minerals

\section{Introduction}

Infancy is a time of rapid physical growth as well as physiological, immunological and mental development. Malnutrition from inadequate complementary feeding is a serious problem in many low income countries where complementary foods consist of starch-based cereals or gruel that may provide sufficient energy but inadequate protein and micronutrients (Dewey, 2003). Micronutrient deficiencies, especially zinc deficiency, are associated with stunting of growth and other serious health consequences including anaemia and a greater susceptibility to infection (Bhutta et al.2008).

Access to energy and nutrient-dense foods during the complementary feeding period, along with appropriate feeding practices and continued breastfeeding is needed to ensure long-term optimal growth and development (Lutter et al., 2003). Although the causes of malnutrition are many and diverse, inadequate intake of foods and essential nutrients has been reported to be a major contributory factor to under-five malnutrition (Sarika et al., 2017; Kikafunda et al., 2003). Besides increased risk of mortality, under nutrition in early life has irreversible effects and serious health consequences such as impaired cognitive function which can result in national economic and productivity loss (Sarika et al., 2017). Studies have shown that at 6 months or less, only 17 percent of mothers in Nigeria are exclusively breastfeeding their infants, and by 6 and 9 months, 63 percent of Nigerian mothers have introduced complementary foods while continuing breastfeeding (NDHS, 2013). Therefore, complementary foods of adequate nutrient densities are needed for optimal growth and development of infants after 6 months of age. 
The first Nigerian Nutrition Network meeting of 2002 also identified poor feeding practices and shortfall in food intake as the important factors responsible for malnutrition and illness among children in Nigeria. The recipes of the traditional complementary foods show that most of them are cereal based except for the egg custard, plantain pudding and yam pottage. More than half of the selected complementary foods were based on the maize gruel (pap) which is the most popular and often the first food introduced to infants by mothers in Nigeria. This is supported by the report by Ibeanu \& Okeke (2001) that pap is the most commonly used complementary food in Nigeria. Yeung (1998) also reported that cereals are usually the first solid foods given to infants because they are readily available and culturally acceptable. These cereals usually form the basis for most of the traditional complementary foods (Onofiok \& Nnanyelugo, 1998). After the successful introduction of cereal gruel from six months, as from eight months and beyond, the introduction of semi-solid to solid complementary foods become imperative to be able to meet energy needs of the infants and young children.

Staple foods in the family menu such as yam, rice, garri, and cocoyam are given to the child (Onofiok \& Nnanyelugo, 1998). In Africa, traditional complementary foods are based on starchy cereals such as maize, sorghum, finger millet and rice, and non-cereals such as cassava, round potato, sweet potato, yams and plantains. These foods have been widely associated with nutrient deficiencies among pre-school age children (Walker, 1990). Yam (Dioscorea spp.) and rice (Oryza sativa) are major staple foods in Nigeria. Yams are rich in phenyl alanine and threonine but limiting in valine and tryptophan (Ogunlade et al. 2011), whilst rice is rich in carbohydrate but deficient in lysine, thus making their protein quality poorer than that of animals.

There is therefore need for strategic use of inexpensive high protein sources that complement the protein quality of these staple foods in order to enhance their nutritional value. Traditional complementary foods could be improved upon by combining locally available foods that complement each other in such a way that new pattern of protein quality created by this combination is similar to that recommended for infants (Okafor et al., 2008). Insects constitute quality food and feed, have high feed conversion ratios, and emit low level of greenhouse gases (van Huis, 2013). An upsurge of interest in the use of insects as sustainable diets is being encouraged as many of them are nutritionally, economically and ecologically important.

Africa insects are rich in protein and usually processed to tasty food products which are used as flavour intensifiers in soups and stews, and also add protein to protein-poor diets. Dried caterpillar has been used with cereal to prepare infant and young child complementary foods in

Democratic Republic of Congo (Bauserman et al., 2015) and found acceptable to mothers and children. Dried insects may be crushed or pulverized, and raw or boiled insects ground or mashed to become masses of protein and lipids that can be mixed with other foodstuffs such as grain, ground meat and mashed potatoes to make a variety of dishes (Mitsuhashi, 2010). The objective of this study, which is a follow up on the previous one on the use of $M$. bellicosus in enriching gruels from maize and sorghum, was to assess nutritional quality and safety of Macrotermes bellicosus-enriched locally formulated complementary foods using animal model.

\section{Materials and Methods}

\subsection{Sample Collection and Preparation}

Macrotermes bellicosus (MB) were collected during their swarming in Oyo and Ekiti States, Nigeria, dried for 10 minutes over a gas cooker using a frying pan, cooled, dewinged and refrigerated at $-4^{\circ} \mathrm{C}$. About $1.5 \mathrm{~kg}$ each of White yam (Disscorea rotundata) and Aroso rice (Oryza sativa) were purchased from Bodija market in Ibadan. Bodija market is one of the major markets in Nigeria where agricultural produce from different parts of the country and imported food items are being sold, hence food items purchased from this market are representative of such commodities. Sample of raw Aroso rice was cleansed of extraneous matter such as stones and chaff by hand picking. The rice was boiled for about 30 minutes at $100^{\circ} \mathrm{C}$ to a pastry form and mashed. The yam tubers were washed, peeled, sliced and boiled for about 30 minutes at $100^{\circ} \mathrm{C}$ to dryness with calculated amount of distilled water, and mashed. The two mashed samples (rice and yam) were oven-dried for 18 hours at $60^{\circ} \mathrm{C}$. The dried rice and yam samples were separately milled into flour with Malex blender (DMN/DIC/PMT/02- 03/206, Kanchan International Limited), packed in cellophane nylon and kept air tight in the laboratory of Department of Human Nutrition, University of Ibadan, till when needed. Dried MB was also milled using the blender (Bauserman et al., 2015).

Various samples of basal complementary foods were prepared as follows:

Sample BR $=100 \mathrm{~g}$ Boiled rice, Sample $\mathrm{BR}_{1}=90 \mathrm{~g}$ Boiled rice $+10 \mathrm{~g}$ M. bellicosus

Sample $\mathrm{BR}_{2}=85 \mathrm{~g}$ Boiled rice $+15 \mathrm{~g}$ M. bellicosus Sample $\mathrm{BR}_{3}=80 \mathrm{~g}$ Boiled rice $+20 \mathrm{~g}$ M. bellicosus, Sample BY $=100 \mathrm{~g}$, Boiled yam, Sample BY $1=90 \mathrm{~g}$ Boiled yam $+10 \mathrm{~g}$ M. bellicosus 
Sample $\mathrm{BY}_{2}=85 \mathrm{~g}$ Boiled yam $+15 \mathrm{~g}$ M. bellicosus, Sample $\mathrm{BY}_{3}=80 \mathrm{~g}$ Boiled yam $+20 \mathrm{~g}$ M. bellicosus

\subsection{Proximate Composition Analysis}

Moisture content of the samples was determined by air oven at $105^{\circ} \mathrm{C}$ (Plus 11 Sanyo Gallenkamp PLC UK) for 4 hours. Crude protein of the samples was determined using micro-Kjeldahl method (Method No 978.04, AOAC, 2005). Crude lipid was determined by Soxhlet extraction method (Method No 930.09, AOAC, 2005) and the crude lipid estimated as $\mathrm{g} / 100 \mathrm{~g}$ of sample. The ash content was determined by weighing $5 \mathrm{~g}$ of sample in triplicate and heated in a muffle furnace (Gallenkamp, size 3) at $550^{\circ} \mathrm{C}$ for $4 \mathrm{~h}$ ( Method No 930.05 , AOAC, 2005). The total carbohydrate content was obtained by difference. Gross energy of the samples was determined using ballistic bomb calorimeter (Manufacturer: Cal 2k - Eco, TUV Rheinland Quality Services (Pty) Ltd, South Africa).

\subsection{Mineral Analysis}

Potassium and sodium content of the samples were determined by digesting the ash of the samples with perchloric acid and nitric acid, and then taking the readings on Jenway digital flame photometer/spectronic20 (AOAC, 2005: (975.11)). Phosphorus was determined by Vanado- molybdate colorimetric method (AOAC, 2005: (975.16)). Calcium, magnesium, iron, zinc, manganese, and copper were determined spectrophotometrically using Buck 200 atomic absorption spectrophotometer (Buck Scientific, Norwalk) and compared with absorption of standards of these minerals (AOAC, 2005: (975.23).

\subsection{Vitamin Analysis}

Vitamin A Determination Vitamin A was determined through ultraviolet absorption measurement at $328 \mathrm{~nm}$ after extraction with chloroform. Calibration curve of vitamin A acetate was made and sample vitamin A concentration estimated as microgram ( $\mu \mathrm{g}$ ) of vitamin A acetate. 2.4.2 Thiamine (Vitamin $\mathrm{B}_{1}$ ) Determination Thiamine content of the sample was determined by weighing $1 \mathrm{~g}$ of it into $100 \mathrm{ml}$ volumetric flask and adding $50 \mathrm{ml}$ of $0.1 \mathrm{M}$

$\mathrm{H}_{2} \mathrm{SO}_{4}$ and boiled in a boiling water bath with frequent shaking for 30 minutes. $5 \mathrm{ml}$ of $2.5 \mathrm{M}$ sodium acetate solution was added and flask set in cold water to cool contents below $50^{\circ} \mathrm{C}$. The flask was stoppered and kept at $45-50^{\circ} \mathrm{C}$ for 2 hours and thereafter made up to $100 \mathrm{ml}$ mark. The mixture was filtered through a No. 42 Whatman filter paper, discarding the first $10 \mathrm{ml} .10 \mathrm{ml}$ was pipetted from remaining filterate into a $50 \mathrm{ml}$ volumetric flask and $5 \mathrm{ml}$ of acid potassium chloride solution was added with thorough shaking. Standard thiamine solutions were prepared and treated same way. The absorbance of the sample as well as that of the standards was read on a fluorescent UV Spectrophotometer (Cecil A20 Model) at a wavelength of $285 \mathrm{~nm}$.

\subsubsection{Riboflavin (Vitamin $\mathrm{B}_{2}$ ) Determination}

Riboflavin of the samples was determined by weighing $1 \mathrm{~g}$ of each sample into a $250 \mathrm{ml}$ volumetric flask, $5 \mathrm{ml}$ of $1 \mathrm{M} \mathrm{HCl}$ was added, followed by the addition of $5 \mathrm{ml}$ of dichloroethene. The mixture was shaken and $90 \mathrm{ml}$ of de-ionized water was added. The whole mixture was thoroughly shaken and was heated on a steam bath for 30 minutes to extract all the riboflavin. The mixture was then cooled and made up to volume with de-ionized water. It was then filtered, discarding the first $20 \mathrm{ml}$ of the aliquot. $2 \mathrm{ml}$ of the filterate obtained was pipetted into another $250 \mathrm{ml}$ volumetric flask and made up to mark with de-ionized water. Sample was read on the fluorescent spectrophotometer at a wavelength of $460 \mathrm{~nm}$. Standard solutions of riboflavin were prepared and readings taken at $460 \mathrm{~nm}$, and the sample riboflavin obtained through calculation.

\subsubsection{Niacin (Vitamin $\mathrm{B}_{3}$ ) Determination}

About $5 \mathrm{~g}$ of sample was extracted with $100 \mathrm{ml}$ of distilled water and $5 \mathrm{ml}$ of this solution was drawn into $100 \mathrm{ml}$ volumetric flask and make up to mark with distilled water. Standard solutions of niacin were prepared and absorbance of sample and standard solutions were measured at a wavelength of $385 \mathrm{~nm}$ on a spectrophotometer and niacin concentration of the sample estimated.

\subsubsection{Pyridoxine (Vitamin $\mathrm{B}_{6}$ ) Determination}

The vitaminB $B_{6}$ content of the sample was determined by extracting $1 \mathrm{~g}$ of sample with $0.5 \mathrm{~g}$ of ammonium chloride, $45 \mathrm{ml}$ of chloroform and $5 \mathrm{ml}$ of absolute ethanol. The mixture was thoroughly mixed in a separating funnel by shaking for $30 \mathrm{mins}$, and $5 \mathrm{ml}$ of distilled water added. The chloroform layer containing the pyridoxine was filtered into a $100 \mathrm{ml}$ volumetric flask and made up to mark with chloroform. $0-10 \mathrm{ppm}$ of vitamin $\mathrm{B}_{6}$ standard solutions were prepared and treated in a similar way as sample, and their absorbance measured on Cecil $505 \mathrm{E}$ spectrophotometer at $415 \mathrm{mn}$. The amount of vitamin $\mathrm{B}_{6}$ in the sample was then calculated. 


\subsubsection{Cyanocobalamin (Vitamin $\mathrm{B}_{12}$ ) Determination}

Cyanocobalamin content of the sample was determined by extracting $1 \mathrm{~g}$ of sample with distilled water with shaking for $45 \mathrm{~min}$ followed by filtering the mixture. The first $20 \mathrm{ml}$ of the filterate was rejected, and another $20 \mathrm{mls}$ filtrate collected. To the collected filtrate, $5 \mathrm{mls}$ of $1 \%$ Sodium dithionite solution was added. Standard cyanocobalamin solutions $(0-10 \mu \mathrm{g} / \mathrm{ml})$ were prepared and absorbance of sample as well as standard was read on spectronic21D spectrophotometer at $445 \mathrm{~nm}$. The amount of sample cyanocobalamin was then estimated through calculation.

\subsubsection{Ascorbic Acid Determination}

Ascorbic acid in the sample was determined by titrating its aqueous extract with solution of 2, 6dichlorophenol-indophenol dye to a faint pink end point.

\subsection{Antinutrient Analysis}

Oxalate was determined by extraction of the samples with water for about three hours and standard solutions of oxalic acid prepared and read on spectrophotometer (Spectronic20) at $420 \mathrm{~nm}$. The absorbance of the samples was also read and amount of oxalate estimated. Phytate was determined by titration with ferric chloride solution (Sudarmadji \& Markakis, 1977); while trypsin inhibitory activity was determined on casein and comparing the absorbance with that of trypsin standard solutions read at $280 \mathrm{~nm}$ (Makkar \& Becker, 1996). The tannin content was determined by extracting the samples with a mixture of acetone and acetic acid for five hours, measuring their absorbance and comparing the absorbance of the sample extracts with the absorbance of standard solutions of tannic acid at $500 \mathrm{~nm}$ on spectronic20 (Griffiths \& Jones 1977). Saponin was also determined by comparing the absorbance of the sample extracts with that of the standard at $380 \mathrm{~nm}$ (Makkar \& Becker, 1996). All determinations were carried out in triplicate.

\subsection{Micronutrient Bioavailablity and Histopathological Study}

\subsubsection{Rat Feeding Trial}

Four iso-caloric diets, of which three sets were iso-nitrogenous, comprising a basal diet, two experimental diets (yam and rice at $20 \% \mathrm{MB}$ inclusion level) and casein diet (control) were prepared as shown in Table 1. Twenty four weanling albino rats of Wister strain brand of not more than 24-day old were purchased from Physiology Department, University of Ibadan, and were housed individually in metabolic cages at the Department of Animal Science, University of Ibadan. The animal house was maintained at a $12 \mathrm{~h}$ light-dark cycle, constant temperature of $20 \pm 3^{\circ} \mathrm{C}$ and relative humidity of $65 \pm 15 \%$. The rats were allowed to acclimatise for one week, fed ad libitum with commercial rat pellets and clean tap water. At the end of seven days, they were weighed and then randomly distributed to four diet groups of six rats per group based on their weight. An amount of $10 \mathrm{~g}$ of prepared diets was supplied to each rat on daily basis and water was changed every other day for 21 days. The left-over of the diets were collected and weighed on daily basis. The rats were weighed on a weekly basis throughout the duration of the experiment (Ayatse et al., 1985). 
Table 1. Composition of formulated rats diets $(\mathrm{g})$

\begin{tabular}{lllll}
\hline Nutrient & Basal diet & Yam diet & Rice diet & Control diet \\
\hline Starch & 1033.2 & 499.9 & 506.8 & 778.2 \\
Cellulose & 63 & 63 & 63 & 63 \\
Vegetable oil & 100.8 & 100.8 & 100.8 & 100.8 \\
Minerals & 50.4 & 50.4 & 50.4 & 50.4 \\
Vitamins & 12.6 & 12.6 & 12.6 & 12.6 \\
$\mathrm{BY}_{3}$ & - & 533.3 & - & - \\
$\mathrm{BR}_{3}$ & - & - & 526.4 & - \\
Casein & - & - & - & 280.0 \\
TOTAL & 1260 & 1260 & 1260 & 1260 \\
\hline
\end{tabular}

\subsubsection{Serum Analysis for Zinc, Calcium and Ferritin}

Ocular bleeding method of collecting blood from the orbital sinus was employed (Janet Hoff, 2000). On the 28th day of feeding trial, blood sample of each rat was taken. The rats were anesthetized using chloroform and blood collected in ETDA bottles containing anticoagulant, and digested a clear colourless solution with concentrated $\mathrm{HNO}_{3}, \mathrm{H}_{2} \mathrm{O}_{2}$ deionized water. The concentration of calcium, iron and zinc were read on a Buck 211 VGP atomic absorption spectrophotometer using their hollow cathode lamp at their respective wavelength (AOAC, 2006).

\subsubsection{Determination of Serum Retinol}

A $0.5 \mathrm{ml}$ homogenized blood sample was refluxed with methanol and potassium hydroxide solution in a water bath at $100^{\circ} \mathrm{C}$ for 30 minutes, cooled in ice and kept in the dark for 1 hour. Standard solution of the mixture was prepared by adding methanol: $\mathrm{H}_{2} \mathrm{O}(3: 1)$ mixture and made up to the mark in a $250 \mathrm{ml}$ volumetric flask and kept in the dark overnight. The absorbance of resulting solution as well as standards were read on a cecil 2483 spectrophotometer at a wavelength of $430 \mathrm{~nm}$ and vitamin A concentration as retinol equivalent was calculated.

\subsubsection{Histological Study of Rat Organs}

Histopathological study was carried out on the kidney, liver and spleen of the rats by preparing slides of the rat organs and examining them under the microscope. Photomicrographs were taken at $\times 40, \times 100$ and $\times 400$ magnifications.

\subsection{Statistical analysis}

Data was analysed using SPSS (Statistical Package for Social Science) version 15.0. The data obtained were subjected to analysis of variance (ANOVA), Fisher's Least Significance Difference and Duncan multiple range tests at $\mathrm{p}<0.05$

\section{Results}

\subsection{Proximate Composition of M. bellicosus, Boiled Yam and Rice and Complementary Foods}

The result of proximate composition of roasted M. bellicosus, boiled yam and rice is as shown in Table 2(A). Roasted $M$. bellicosus has low moisture content while the crude protein, fat, carbohydrate and gross energy content were very high. The moisture, crude protein and crude fat content of both boiled yam and rice were low, while the ash and total carbohydrates content were moderately high. The moisture and crude protein values of boiled yam were significantly higher than boiled rice $(p>0.05)$. There was no significant difference in crude fat and ash values of the samples. Boiled rice was significantly higher in total carbohydrate and gross energy $(\mathrm{p}<0.05)$ than boiled yam. In Table 2(B), moisture content of the formulated complementary foods reduced significantly, it continue to reduce with increase in quantity of MB inclusion $(p<0.05)$. Significant differences also exist between the enriched complementary foods, the level of reduction in moisture content increasing with increase in inclusion level $(\mathrm{p}<0.05)$. There were significant increase in values of crude protein, fat, ash, gross energy and decrease in total carbohydrate of the enriched rice and yam complementary foods $(\mathrm{p}<0.05)$.

\subsection{Mineral Composition of M. bellicosus, Boiled Rice and Yam and Formulated Complementary Foods}

M. bellicosus is a rich source of potassium, calcium, phosphorus, zinc, and copper, moderate in sodium, iron and manganese, but low in magnesium (Table 3(A)). Boiled rice and yam are good sources of magnesium, phosphorus and calcium, moderate in potassium, sodium, iron and zinc respectively. Boiled yam was significantly higher in all the minerals compared with boiled rice $(\mathrm{p}<0.05)$. 
Table 2(A). Proximate composition of roasted M. bellicosus, Boiled rice and yam (g/100g dry matter)

\begin{tabular}{lllll}
\hline & & \multicolumn{2}{l}{ Boiled rice (BR) } & Boiled yam (BY) \\
\hline Sample & M. bellicosus & (Dry) & (Dry) & RV \\
Moisture & $4.0 \pm 0.04$ & $5.52 \pm 0.04$ & $7.17 \pm 0.02$ & $\leq 5$ \\
Crude Protein & $31.8 \pm 0.10$ & $3.78 \pm 0.11$ & $5.90 \pm 0.09$ & $\geq 15$ \\
Crude Fat & $16.4 \pm 0.03$ & $2.66 \pm 0.61$ & $2.40 \pm 0.03$ & $10-25$ \\
Ash & $3.8 \pm 0.03$ & $2.70 \pm 0.02$ & $2.57 \pm 0.02$ & $\leq 3$ \\
Total Carbohydrates & $43.0 \pm 0.10$ & $85.38 \pm 0.70$ & $81.98 \pm 0.09$ & $64 \pm 4$ \\
Gross Energy (kcal/) & $450.7 \pm 0.00$ & $380.50 \pm 0.00$ & $373.12 \pm 0.00$ & $400-425$ \\
\hline
\end{tabular}

Values are means \pm standard deviations of triplicate determinations .(CODEX CAC/GL08.Rev. 2013): Codex alimentarius: Guidelines on formulated complementary foods for older infants and young children RV = Recommended values $(\mathrm{g} / 100 \mathrm{~g})$

Table 2(B). Proximate composition of enriched complementary foods (g/100)

\begin{tabular}{lcccccc}
\hline Sample & Moisture & C. Protein & C. Fat & Ash & T. Carbohydrates & G E \\
\hline BR & $5.52 \pm 0.04^{\mathrm{a}}$ & $3.78 \pm 0.11^{\mathrm{c}}$ & $2.66 \pm 0.61^{\mathrm{l}}$ & $2.70 \pm 0.02^{\mathrm{h}}$ & $85.34 \pm 0.70^{\mathrm{c}}$ & $380.42 \pm 0.00^{\mathrm{r}}$ \\
$\mathrm{BR}_{1}$ & $5.40 \pm 0.02^{\mathrm{c}}$ & $11.57 \pm 0.11^{\mathrm{z}}$ & $3.57 \pm 0.03^{\mathrm{h}}$ & $3.33 \pm 0.02^{\mathrm{a}}$ & $76.12 \pm 0.02^{\mathrm{p}}$ & $382.89 \pm 0.01^{\mathrm{r}}$ \\
$\mathrm{BR}_{2}$ & $4.58 \pm 0.02^{\mathrm{b}}$ & $13.78 \pm 0.10^{\mathrm{y}}$ & $3.86 \pm 0.03^{\mathrm{c}}$ & $3.69 \pm 0.02^{\mathrm{s}}$ & $74.09 \pm 0.10^{\mathrm{q}}$ & $386.22 \pm 0.01^{\mathrm{c}}$ \\
$\mathrm{BR}_{3}$ & $4.01 \pm 0.03^{\mathrm{k}}$ & $15.31 \pm 0.05^{\mathrm{j}}$ & $4.08 \pm 0.03^{\mathrm{s}}$ & $4.16 \pm 0.03^{\mathrm{d}}$ & $72.52 \pm 0.22^{\mathrm{f}}$ & $388.04 \pm 0.00^{\mathrm{c}}$ \\
$\mathrm{BY}$ & $7.17 \pm 0.02^{\mathrm{j}}$ & $5.90 \pm 0.09^{\mathrm{l}}$ & $2.40 \pm 0.03^{\mathrm{e}}$ & $2.57 \pm 0.02^{\mathrm{c}}$ & $81.98 \pm 0.09^{\mathrm{k}}$ & $373.12 \pm 0.00^{\mathrm{e}}$ \\
$\mathrm{BY}_{1}$ & $7.02 \pm 0.04^{\mathrm{d}}$ & $7.88 \pm 0.10^{\mathrm{k}}$ & $2.89 \pm 0.03^{\mathrm{e}}$ & $4.06 \pm 0.03^{\mathrm{r}}$ & $75.99 \pm 0.12^{\mathrm{h}}$ & $381.48 \pm 0.00^{\mathrm{s}}$ \\
$\mathrm{BY}_{2}$ & $4.03 \pm 0.04^{\mathrm{e}}$ & $11.44 \pm 0.11^{\mathrm{b}}$ & $5.28 \pm 0.03^{\mathrm{m}}$ & $4.45 \pm 0.03^{\mathrm{h}}$ & $74.80 \pm 0.15^{\mathrm{n}}$ & $392.48 \pm 0.00^{\mathrm{k}}$ \\
$\mathrm{BY}_{3}$ & $4.02 \pm 0.02^{\mathrm{a}}$ & $15.26 \pm 0.08^{\mathrm{c}}$ & $5.02 \pm 0.03^{\mathrm{m}}$ & $4.20 \pm 0.03^{\mathrm{h}}$ & $71.48 \pm 0.10^{\mathrm{c}}$ & $392.14 \pm 0.00^{\mathrm{h}}$ \\
*RV $^{\mathrm{R} V}$ & $<5$ & $>15$ & $10-25$ & $<3$ & 64 & $400-425$ \\
\hline
\end{tabular}

Values are means \pm standard deviations of triplicate determinations. Means with different superscripts in a column are significantly different $(p<0.05) . * \mathrm{RV}=$ Recommended values $(\mathrm{g} / 100 \mathrm{~g}) *(\mathrm{CODEX}$ CAC/GL 08. Rev. 2013): Codex alimentarius: Guidelines on formulated complementary foods for older infants and young children. $\mathrm{BR}=100 \mathrm{~g}$ boiled rice sample; $\mathrm{BR}_{1}=90 \mathrm{~g}$ boiled rice $+10 \mathrm{~g}$ M. bellicosus sample, $\mathrm{BR}_{2}=85 \mathrm{~g}$ boiled rice $+15 \mathrm{~g}$ M. bellicosus sample; $\mathrm{BR}_{3}=80 \mathrm{~g}$ boiled rice $+20 \mathrm{~g}$ M. bellicosus sample $\mathrm{BY}=100 \mathrm{~g}$ boiled yam sample; $\mathrm{BY}_{1}=$ $90 \mathrm{~g}$ boiled yam $+10 \mathrm{~g}$ M. bellicosus sample; $\mathrm{BY}_{2}=85 \mathrm{~g}$ boiled yam $+15 \mathrm{~g}$ M. bellicosus sample, and $\mathrm{BY}_{3}=80 \mathrm{~g}$ boiled yam $+20 \mathrm{~g} M$. bellicosus sample

Adding M. bellicosus to boiled rice and yam (Tables (3B) and (3C)) brought about significant increase in minerals $(\mathrm{p}<0.05)$ in the formulated complementary foods; the values increased with increase in inclusion level of $M$. bellicosus. However, the mineral content of the formulated complementary foods were lower than the recommended values by FAO/WHO. The values of the minerals of enriched complementary foods were significantly different from one another $(\mathrm{p}<0.05)$, for boiled rice and yam, the $10 \% \mathrm{M}$. bellicosus incorporated diets having the lowest values while $20 \%$ M. bellicosus incorporated food samples had the highest values.

\subsection{Vitamin Composition of Boiled Rice and Yam and M. bellicosus Enriched Complementary Foods}

Vitamin composition of boiled rice, boiled yam and M. bellicosus enriched complementary foods is shown in Tables 4 (A) and (B) respectively. Addition of M. bellicosus increased significantly $(\mathrm{p}<0.05)$ the $\beta$-carotene level in boiled rice and yam. Water soluble vitamins such as thiamine, riboflavin and niacin decreased in value in $\mathrm{BR}_{1}$ and $\mathrm{BR}_{2}$. Vitamin $\mathrm{B}_{6}$ level in M. bellicosus- enriched rice complementary foods increased at all levels of addition of the insect, while the addition does not apparently improve the vitamin $\mathrm{C}$ content of the complementary food. In boiled yam (Table 3A) the reverse was the case, as addition of M. bellicosus progressive improved vitamins at all levels of inclusion of the insect.

\subsection{Antinutritional Factors of Boiled Rice, Boiled Yam and Enriched Complementary Foods}

Antinutritional factors in boiled rice, boiled yam and M. bellicosus enriched complementary foods are shown in Tables 5(A) and (B)). Boiled rice and yam were very low in all the antinutritional factors studied. M. bellicosus inclusion does not bring about any observable change in the level of some antinutritional factors, while oxalates and tannins were not detectable at $15 \%$ and $20 \%$ (BR2 and BR3) inclusion level. Trypsin inhibitor was not detected at any level 
Table 3(A). Mineral composition of M. bellicosus, boiled rice and yam (mg/100)

\begin{tabular}{llll}
\hline Parameter & M. bellicosus & Boiled rice (BR) & Boiled yam (BY \\
\hline Potassium & $361.13 \pm 0.31$ & $80.04 \pm 0.00$ & $120.00 \pm 0.00$ \\
Sodium & $98.40 \pm 0.20$ & $30.00 \pm 0.00$ & $90.00 \pm 0.00$ \\
Calcium & $227.50 \pm 0.20$ & $70.03 \pm 0.00$ & $120.00 \pm 0.00$ \\
Magnesium & $24.33 \pm 0.15$ & $140.02 \pm 0.00$ & $160.03 \pm 0.00$ \\
Phosphorus & $361.30 \pm 0.20$ & $210.01 \pm 0.00$ & $290.01 \pm 0.00$ \\
Iron & $2.07 \pm 0.25$ & $4.20 \pm 0.04$ & $5.60 \pm 0.03$ \\
Zinc & $15.03 \pm 0.31$ & $1.18 \pm 0.02$ & $1.53 \pm 0.02$ \\
Manganese & $2.35 \pm 0.25$ & $0.53 \pm 0.15$ & $0.81 \pm 0.03$ \\
Copper & $5.07 \pm 0.54$ & $0.37 \pm 0.35$ & $0.43 \pm 0.21$ \\
\hline
\end{tabular}

Values are mean \pm standard deviation of triplicate determinations.

Table 3(B). Mineral composition of enriched rice complementary foods ( $\mathrm{mg} / 100 \mathrm{~g})$

\begin{tabular}{llllll}
\hline Parameter & $\mathrm{BR}$ & $\mathrm{BR}_{1}$ & $\mathrm{BR}_{2}$ & $\mathrm{BR}_{3}$ & $* \mathrm{RV}$ \\
\hline Potassium & $80.04 \pm 0.00^{\mathrm{a}}$ & $158.70 \pm 0.46^{\mathrm{b}}$ & $170.07 \pm 0.51^{\mathrm{c}}$ & $176.63 \pm 0.51^{\mathrm{d}}$ & 516 \\
Sodium & $30.00 \pm 0.00^{\mathrm{a}}$ & $102.67 \pm 0.25^{\mathrm{b}}$ & $109.10 \pm 0.36^{\mathrm{c}}$ & $113.63 \pm 0.45^{\mathrm{d}}$ & 296 \\
Calcium & $70.03 \pm 0.00^{\mathrm{a}}$ & $242.23 \pm 0.50^{\mathrm{b}}$ & $252.13 \pm 0.29^{\mathrm{c}}$ & $258.06 \pm 0.42^{\mathrm{d}}$ & 500 \\
Magnesium & $140.02 \pm 0.00^{\mathrm{a}}$ & $24.10 \pm 0.40^{\mathrm{b}}$ & $25.93 \pm 0.35^{\mathrm{c}}$ & $27.13 \pm 0.35^{\mathrm{d}}$ & 60 \\
Phosphorus & $210.01 \pm 0.00^{\mathrm{a}}$ & $359.40 \pm 1.57^{\mathrm{b}}$ & $372.40 \pm 0.30^{\mathrm{c}}$ & $381.76 \pm 0.57^{\mathrm{d}}$ & 460 \\
Iron & $4.20 \pm 0.04^{\mathrm{a}}$ & $2.40 \pm 0.20^{\mathrm{b}}$ & $2.80 \pm 0.30^{\mathrm{c}}$ & $3.23 \pm 0.35^{\mathrm{d}}$ & 11.6 \\
Zinc & $1.18 \pm 0.02^{\mathrm{a}}$ & $2.40 \pm 0.20^{\mathrm{b}}$ & $2.67 \pm 0.40^{\mathrm{c}}$ & $2.73 \pm 0.35^{\mathrm{d}}$ & 8.3 \\
Manganese & $0.53 \pm 0.15^{\mathrm{a}}$ & $2.50 \pm 0.12^{\mathrm{b}}$ & $2.62 \pm 0.42^{\mathrm{c}}$ & $2.83 \pm 0.42^{\mathrm{d}}$ & $0.60^{* *}$ \\
Copper & $0.37 \pm 0.35^{\mathrm{a}}$ & $0.49 \pm 0.60^{\mathrm{b}}$ & $0.57 \pm 0.35^{\mathrm{c}}$ & $0.65 \pm 0.40^{\mathrm{d}}$ & $0.34^{* *}$ \\
\hline
\end{tabular}

Values are mean \pm standard deviation of triplicate determinations. Mean value with different superscripts in a row are significantly different $(\mathrm{p}<0.05) . * \mathrm{RV}=$ Recommended values $(\mathrm{mg} / 100 \mathrm{~g}) *(\mathrm{CODEX}$ CAC/GL 08.Rev. 2013) Codex alimentarius: Guidelines on formulated complementary foods for older infants and young children **RDA (Sareen, Jack \& James, 2009).

Table 3(C). Mineral composition of formulated yam complementary Foods (mg/100g)

\begin{tabular}{llllll}
\hline Parameter & BY & $\mathrm{BY}_{1}$ & $\mathrm{BY}_{2}$ & $\mathrm{BY}_{3}$ & $* \mathrm{RV}$ \\
\hline Potassium & $120.00 \pm 0.00^{\mathrm{e}}$ & $162.20 \pm 0.36^{\mathrm{f}}$ & $174.10 \pm 0.45^{\mathrm{g}}$ & $181.50 \pm 0.30^{\mathrm{h}}$ & 516 \\
Sodium & $90.00 \pm 0.00^{\mathrm{e}}$ & $99.70 \pm 0.50^{\mathrm{f}}$ & $110.63 \pm 0.42^{\mathrm{g}}$ & $116.00 \pm 0.36^{\mathrm{h}}$ & 296 \\
Calcium & $120.00 \pm 0.00^{\mathrm{e}}$ & $232.90 \pm 15.68^{\mathrm{f}}$ & $253.87 \pm 0.35^{\mathrm{g}}$ & $264.50 \pm 0.30^{\mathrm{h}}$ & 500 \\
Magnesium & $160.03 \pm 0.00^{\mathrm{e}}$ & $25.87^{\mathrm{g}} \pm 0.25^{\mathrm{f}}$ & $28.17 \pm 0.32^{\mathrm{g}}$ & $31.47^{\mathrm{j}} \pm 0.25^{\mathrm{h}}$ & 60 \\
Phosphorus & $290.01 \pm 0.00^{\mathrm{e}}$ & $359.43^{\mathrm{s}} \pm 1.06^{\mathrm{f}}$ & $380.20 \pm 0.87^{\mathrm{g}}$ & $392.83 \pm 0.31^{\mathrm{h}}$ & 460 \\
Iron & $5.60 \pm 0.03^{\mathrm{e}}$ & $2.57 \pm 0.25^{\mathrm{f}}$ & $3.37^{1} \pm 0.25^{\mathrm{g}}$ & $4.40 \pm 0.20^{\mathrm{h}}$ & 11.6 \\
Zinc & $1.53 \pm 0.02^{\mathrm{e}}$ & $16.10 \pm 0.20^{\mathrm{f}}$ & $17.57 \pm 0.25^{\mathrm{g}}$ & $19.80 \pm 0.30^{\mathrm{h}}$ & 8.3 \\
Manganese & $0.81 \pm 0.03^{\mathrm{e}}$ & $25.03 \pm 0.31^{\mathrm{f}}$ & $27.17 \pm 0.35^{\mathrm{g}}$ & $30.00 \pm 0.36^{\mathrm{h}}$ & $0.60^{* *}$ \\
Copper & $0.43 \pm 0.21^{\mathrm{e}}$ & $5.23 \pm 0.12^{\mathrm{f}}$ & $6.50 \pm 0.20^{\mathrm{g}}$ & $7.40 \pm 0.20^{\mathrm{h}}$ & $0.34^{* *}$ \\
\hline
\end{tabular}

Values are means \pm standard deviations of triplicate determinations. Mean value with different superscripts in a row are significantly different $(\mathrm{p}<0.05 * \mathrm{RV}=$ Recommended values $(\mathrm{mg} / 100 \mathrm{~g}) *(\mathrm{CODEX}$ CAC/GL 08. Rev. 2013) Codex alimentarius: Guidelines on formulated complementary foods for older infants and young children **RDA (Sareen, Jack \& James, 2009).

Table 4(A). Vitamin composition of enriched rice complementary foods ( $\mathrm{mg} / 100 \mathrm{~g}$ )

\begin{tabular}{lllll}
\hline Parameter & $\mathrm{BR}_{1}$ & $\mathrm{BR}_{2}$ & $\mathrm{BR}_{3}$ & $* \mathrm{RV}$ \\
\hline Vitamin A $(\mu \mathrm{g} /)^{50.13 \pm 0.31^{\mathrm{a}}}$ & $58.97 \pm 0.42^{\mathrm{b}}$ & $61.47 \pm 0.25^{\mathrm{c}}$ & 400 \\
Thiamine & $0.29 \pm 0.02^{\mathrm{a}}$ & $0.39 \pm 0.02^{\mathrm{b}}$ & $0.45 \pm 0.02^{\mathrm{c}}$ & 0.5 \\
Riboflavin & $0.01 \pm 0.02^{\mathrm{a}}$ & $0.02 \pm 0.01^{\mathrm{b}}$ & $0.03 \pm 0.02^{\mathrm{c}}$ & 0.5 \\
Niacin & $0.61 \pm 0.03^{\mathrm{a}}$ & $0.69 \pm 0.03^{\mathrm{b}}$ & $0.81 \pm 0.03^{\mathrm{c}}$ & 6 \\
Vitamin $_{6}$ & $1.07 \pm 0.02^{\mathrm{a}}$ & $1.19 \pm 0.02^{\mathrm{b}}$ & $1.26 \pm 0.03^{\mathrm{c}}$ & 0.5 \\
Vitamin C & $0.00 \pm 0.00^{\mathrm{a}}$ & $0.00 \pm 0.00^{\mathrm{b}}$ & $0.00 \pm 0.00^{\mathrm{c}}$ & 30 \\
\hline
\end{tabular}

Values are means \pm standard deviations of triplicate determinations. Means with different superscripts in a row are significantly different $(\mathrm{p}<0.05) . * \mathrm{RV}=$ Recommended values $(\mathrm{mg} / 100 \mathrm{~g}) *($ CODEX CAC/GL 08. Rev. 2013) Codex alimentarius: Guidelines on formulated complementary foods for older infants and young children 
Table 4(B). Vitamin composition of enriched yam complementary foods (mg/100 g)

\begin{tabular}{lcccc}
\hline & $\mathrm{BY}_{1}$ & $\mathrm{BY}_{2}$ & $\mathrm{BY}_{3}$ & $* \mathrm{RV}$ \\
\hline Vitamin A $(\mu \mathrm{g} /)$ & $56.60 \pm 0.30^{\mathrm{f}}$ & $61.33 \pm 0.15^{\mathrm{g}}$ & $64.5 \pm 0.20^{\mathrm{h}}$ & 400 \\
Thiamine & $0.33 \pm 0.02^{\mathrm{f}}$ & $0.38 \pm 0.03^{\mathrm{g}}$ & $0.51 \pm 0.02^{\mathrm{h}}$ & 0.5 \\
Riboflavin & $0.11 \pm 0.02^{\mathrm{f}}$ & $0.14 \pm 0.02^{\mathrm{g}}$ & $0.17 \pm 0.02^{\mathrm{h}}$ & 0.5 \\
Niacin & $0.61 \pm 0.03^{\mathrm{f}}$ & $0.69 \pm 0.02^{\mathrm{g}}$ & $0.82 \pm 0.02^{\mathrm{h}}$ & 6 \\
Vitamin $_{6}$ & $1.16 \pm 0.02^{\mathrm{f}}$ & $1.26 \pm 0.03^{\mathrm{g}}$ & $1.33 \pm 0.03^{\mathrm{h}}$ & 0.5 \\
Vitamin C $^{\mathrm{f}}$ & $0.44 \pm 0.02^{\mathrm{f}}$ & $0.37 \pm 0.03^{\mathrm{g}}$ & $0.25 \pm 0.04^{\mathrm{h}}$ & 30 \\
\hline
\end{tabular}

Values are means \pm standard deviations of triplicate determinations. Means with different superscripts in a row are significantly different $(p<0.05)$. RV=Recommended values $(\mathrm{mg} / 100 \mathrm{~g}) *(\mathrm{CODEX}$ CAC/GL 08. Rev. 2013) Codex alimentarius: Guidelines on formulated complementary foods for older infants and young children

Table 5. Antinutritional factors in boiled rice, yam and enriched complementary foods (mg/100 g)

\begin{tabular}{lccccc}
\hline Sample & Phytate & Oxalate & Tannin & Saponin & T. I (TIU/mg) \\
\hline BR & $0.01 \pm 0.01^{\mathrm{f}}$ & $0.01 \pm 0.00^{\mathrm{f}}$ & $0.00 \pm 0.00 \mathrm{n}$ & $0.04 \pm 0.00^{\mathrm{f}}$ & ND \\
\hline BR1 & $0.01 \pm 0.00^{\mathrm{f}}$ & $0.01 \pm 0.00^{\mathrm{f}}$ & $0.03 \pm 0.00^{\mathrm{f}}$ & $0.01 \pm 0.00^{\mathrm{s}}$ & ND \\
\hline BR2 & $0.01 \pm 0.00^{\mathrm{f}}$ & $0.00 \pm 0.00^{\mathrm{b}}$ & $0.00 \pm 0.00^{\mathrm{n}}$ & $0.01 \pm 0.00^{\mathrm{s}}$ & ND \\
\hline BR3 & $0.01 \pm 0.00^{\mathrm{f}}$ & $0.00 \pm 0.00^{\mathrm{b}}$ & $0.00 \pm 0.00^{\mathrm{n}}$ & $0.01 \pm 0.00^{\mathrm{s}}$ & ND \\
\hline BY & $0.00 \pm 0.00^{\mathrm{a}}$ & $0.00 \pm 0.00^{\mathrm{a}}$ & $0.00 \pm 0.00^{\mathrm{b}}$ & $0.05 \pm 0.00^{\mathrm{a}}$ & ND \\
\hline $\mathrm{BY}_{1}$ & $0.01 \pm 0.00^{\mathrm{b}}$ & $0.01 \pm 0.00^{\mathrm{b}}$ & $0.00 \pm 0.00^{\mathrm{b}}$ & $0.01 \pm 0.00^{\mathrm{b}}$ & ND \\
\hline $\mathrm{BY}_{2}$ & $0.20 \pm 0.00^{\mathrm{c}}$ & $0.11 \pm 0.00^{\mathrm{c}}$ & $0.00 \pm 0.00^{\mathrm{b}}$ & $0.08 \pm 0.00^{\mathrm{c}}$ & ND \\
\hline $\mathrm{BY}_{3}$ & $0.01 \pm 0.00^{\mathrm{d}}$ & $0.00 \pm 0.00^{\mathrm{c}}$ & $0.00 \pm 0.00^{\mathrm{b}}$ & $0.01 \pm 0.00^{\mathrm{b}}$ & ND \\
\hline
\end{tabular}

Mean value with different superscripts in a row are significantly different $(\mathrm{p}<0.05)$.

T. I = Trypsin Inhibitors; ND =Not detected at milligramme level

\subsection{Bioavailability of Selected Minerals and Vitamin in Formulated Complementary Foods}

The serum ferritin of rats on rice and yam groups were significantly higher than the control (Figure 1) $(\mathrm{p}<0.05)$. Experimental animals on rice and yam groups had significantly higher serum zinc than the control and basal groups. The serum zinc values observed in the control and rice groups were not significantly different $(\mathrm{p}>0.05)$. Serum calcium was more bioavailable in yam and rice groups compared to the control and basal groups. The serum retinol level of rats fed with the formulated complementary foods was significantly higher than those fed with control and basal diets $(\mathrm{p}<0.05)$. Total protein values observed in rice group was significantly higher than other groups $(\mathrm{p}<0.05)$.

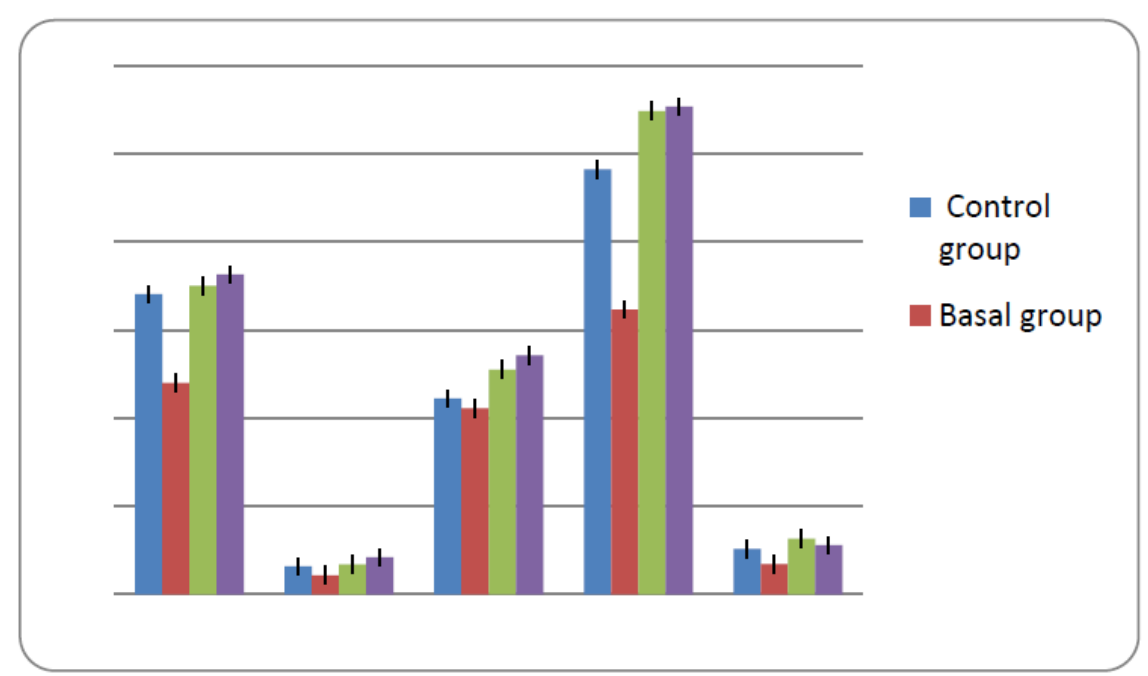

Figure 1. Mean $( \pm$ SD) Bioavailability of selected minerals, vitamin and serum total protein $(\mathrm{mg} / 100 \mathrm{ml})$ of formulated complementary foods, basal diet and control diets $(\mathrm{p}<0.05)$ 


\subsection{Histopathological Assessment of Rats' Organs}

\subsubsection{Rats Kidney}

Histopathological examination of kidney section of rats is shown in Figure 2. Rats from control group (C) showed no histopathological changes and normal structure of renal parenchyma after the feeding trial. It also shows normal glomerular morphology $(\mathrm{G})$ and tubular arrangement. Photomicrograph of kidney of rats from basal group (B) indicated some histopathological changes. These included slight degeneration with increased urinary space size. Rats belonging to rice group $(R)$ also showed normal glomerular morphology $(G)$ and tubular arrangement just like the rats in the control group, while the yam (Y) group was not well processed.

\subsubsection{Rats Liver}

Photomicrographs of liver from rats on different diets are illustrated in Figure 3. Liver from rats on control diet (Plate C) yam diet (Plate Y) displayed normal histological structure of hepatic lobules. They also showed normal morphology of the hepatocyte $(\mathrm{H})$ arrangements with a well-defined central vein $(\mathrm{CV})$. On the other hand, rats fed on basal diet show slightly different hepatocyte arrangement with active macrophage action, indicating slight insult on the liver; while rats fed rice diet showed great insult on the liver as there is a loss of hepatocytes around the $\mathrm{CV}$ area which is radiating outward.

\subsubsection{Rats spleen}

Figure 4 shows the effect of feeding control, basal and experimental diets on the lymphocytes and red to white pulp ratio in the spleen of rats. The photomicrography of rats' spleen fed with the control and rice diets revealed no histopathological changes, and they had normal arrangement of the lymphocytes with the branching pattern of the veins. The rats on basal diet were poorly processed and could not be interpreted. On the other hand, the spleen of rats fed yam diet showed irregular arrangement of lymphocytes.
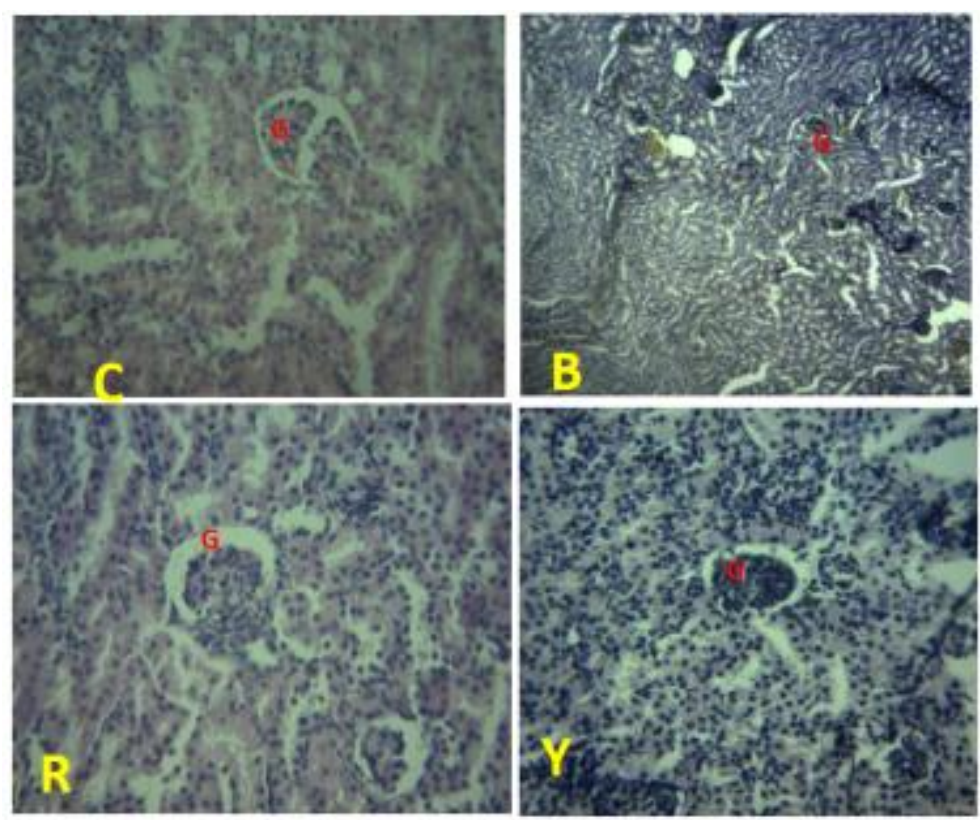

Figure 2. Histomorphology of rats kidneys

$\mathrm{C}=$ Control group, $\mathrm{B}=$ Basal group, $\mathrm{R}=$ Rice group, and $\mathrm{Y}=$ Yam group 

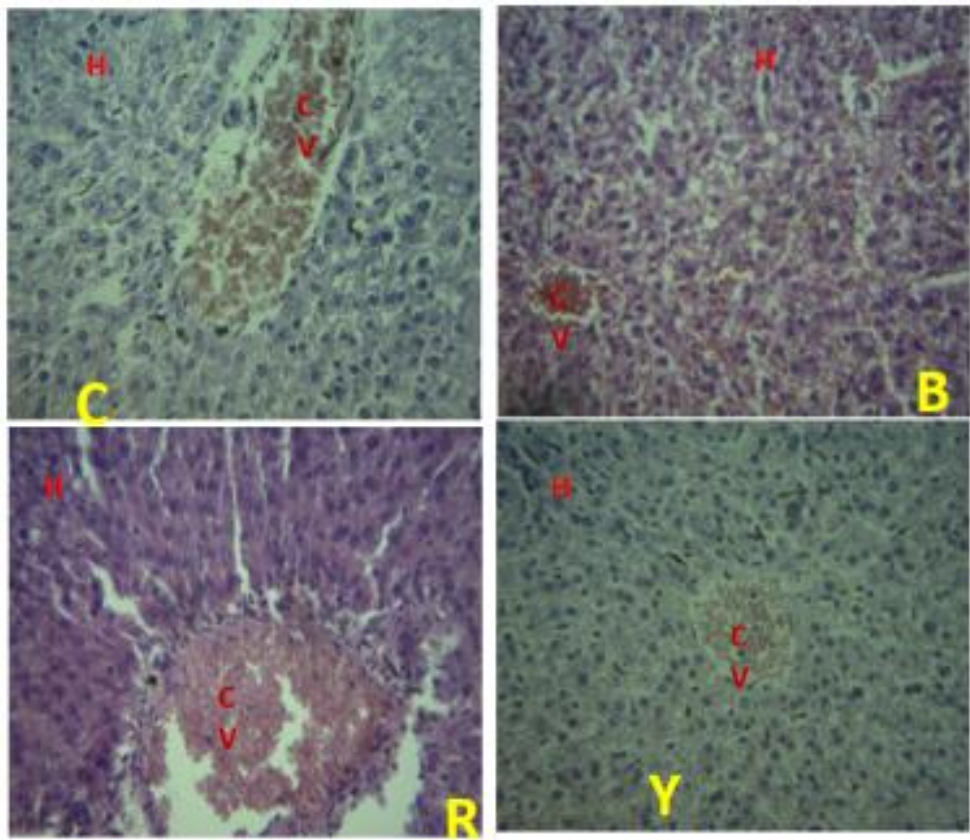

Figure 3. Histomorphology of liver tissue of rats
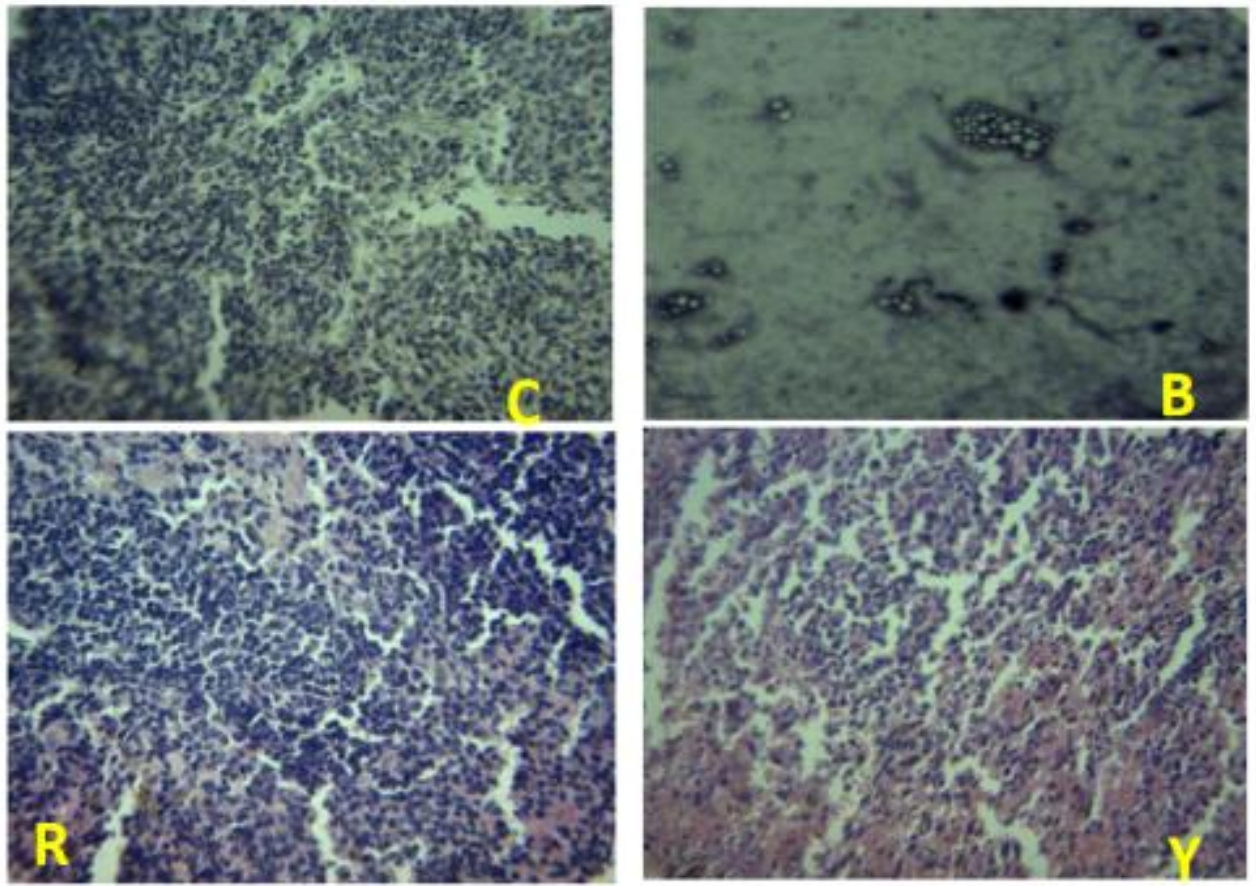

Figure 4. Histomorphology of rats spleen

\section{Discussion}

\subsection{Proximate Composition of Roasted M. bellicosus, Boiled Yam, Rice and Complementary Foods}

The value of moisture content for M. bellicosus in this study is comparable to Adepoju \& Omotayo, (2014). Its low moisture content underscores its high dry matter, and consequently, high macronutrients. The value obtained for the macronutrients of the insect was related to (Adepoju, 2016), and within the range stated for termite (Trinervitermes germinates, Afiukwa et al., 2013). Generally, the insect is rich in crude protein, crude lipid, ash, total carbohydrates and gross energy. The high values of the macronutrients of the insect can contribute significantly to macronutrients of infant complementary foods. The value of crude protein reported in the present 
study falls within the range (33.51-39.74 g/100 g) observed by Kinyuru et al, (2013) for four species of termites, and similar to dried termite $(35.70 \mathrm{~g} / 100 \mathrm{~g}$ ) reported in the NFCT (Sehmi, 1993). Crude protein value of winged termites in this study is superior to raw red meats reported by Williams, (2007) hence, may offer an affordable source of protein for complementary foods.

The moisture content of cooked rice and yam (dry matter basis) used in preparing the rats diets was low and closer to the recommended value ( $\leq 5 \mathrm{~g}$ ) (Table $1(\mathrm{~A})$ ). Food commodities proposed to be used for preparation of dry complementary foods should be properly dried to reduce eventual growth of unwanted microorganisms, and only small amounts should be prepared at a time to avoid extended storage (WHO, 1998; Solomon, 2005). The low moisture content of the raw material may aid the storage quality of the formula, because low moisture content in foods will reduce microbial growth. Both cooked rice and yam were high in total carbohydrates and gross energy content. The high values of total carbohydrates and gross energy content underline why they are used as basic staples for family foods, and can serve well in meeting energy needs of old infants and young children even when fed in little quantity. The reduction in moisture content of M. bellicosus enriched complementary foods was similar to Adepoju \& Daboh (2013) for Cirina forda powder and Adepoju \& Ajayi (2016) for M. bellicosus-enriched maize and sorghum complementary foods. Addition of M. bellicosus to rice and yam resulted in significant increase in protein, fat, ash, total carbohydrate and gross energy content of enriched complementary foods. High energy value of the formulated foods is believed to be due to high lipid and carbohydrate content of the foods. FAO and WHO recommended that foods fed to infants and children should be energy-dense so as to improve total energy intake and the utilization of other nutrients (FAO/WHO, 1998). The formulated rice and yam enriched complementary foods met the recommended values for protein, ash, total carbohydrate, and can supply up to half of fat requirement (CODEX CAC/GL 08. 1991). Feeding infants and young children with the M. bellicosus-enriched complementary foods two times a day may provide the larger part of their recommended value of macronutrient needs on daily basis, especially at $20 \%$ level of inclusion, though our preparations are meant to serve as basic ingredients to which other sources of nutrients and dietary fibre can be added.

\subsection{Mineral Content of M. bellicosus, Boiled Rice, Yam and Formulated Complementary Foods}

The insect is rich in potassium, calcium, phosphorus, zinc, and copper, moderate in sodium, iron and manganese, but low in magnesium (Table 2(A) when compared with the daily requirements of these micronutrients. Boiled rice and yam are high in magnesium, phosphorus and calcium; and moderate in potassium, sodium iron and zinc respectively. Boiled yam was significantly higher in all the minerals compared with boiled rice $(\mathrm{p}<0.05)$. Addition of M. bellicosus to boiled rice (Table 2B) and boiled yam (Table 2C) resulted in significant increase in values of the minerals in all the formulated complementary diets $(\mathrm{p}<0.05)$, the values increasing with increase in its inclusion level. The formulated diets at $15 \%$ and $20 \%$ inclusion levels of M. bellicosus almost met the recommended value for zinc, met that of manganese, while all levels of inclusion can meet recommended value for copper (FAO/WHO 1991). Intake of the formulated complementary foods twice daily can satisfy requirement for calcium and phosphorus, while daily intake of the formulated diets 2-3times at $20 \%$ inclusion of the insect will meet the requirement for iron. Zinc is an essential mineral, vital to human metabolism, growth and immune function (Aggett \& Comerford, 1995). Its deficiency may significantly contribute to stunting in young children. Mild to moderate zinc deficiency may present clinically as impaired growth, which have previously been attributed to other factors (Brown et al., 1998).

Iron deficiency is the most common cause of anemia though other nutrition and non-nutrition related cause can be involved in its origin. Hallberg \& Rossander (1984) reported that anemia is most prevalent in children between 6 and 24 months of age and the major causes are inadequate dietary intake of bioavailable iron, malaria and parasitic infections. Fernandez et al., (2002) reported that prevalence of anaemia is higher during infancy and early childhood than at any other time in the life cycle. The high prevalence is consistent with inadequate intake of dietary iron and low bioavailability in most complementary foods (Lutter, 2003).

\subsection{Vitamin Composition of Boiled Rice, Yam and Formulated Complementary Foods}

Addition of M. bellicosus powder improved the vitamin A content of the enriched foods (Tables 3A and 3B), the observed improvement was due to vitamin A content of the insect, which has been previously reported to be a good source of vitamin A (330.42 $\pm 0.12 \mu \mathrm{g} / 100 \mathrm{~g}$, Adepoju \& Omotayo, 2014). Vitamin A is an antioxidant which prevents cells from damage by free radicals, essential for maintaining healthy eyes and skin, needed for normal growth and reproduction, promotion of healthy immune system and prevention of infections (Rolfe et al., 2009; Roth \& Townsend, 2003). The enriched boiled rice and yam will meet recommended value for vitamin B6 (CODEX CAC/GL 08. 1991). The complementary food were low in water soluble vitamins, hence, their 
alternative sources need to be included in the complete complementary foods since the preparation here are meant for basic ingredients and not complete complementary foods.

\subsection{Antinutrient Composition in Boiled Food Samples and Enriched Complementary Foods}

The boiled rice and yam and Marcrotermes bellicosus-enriched samples were very low in the antinutritional factors studied. Addition of M. bellicosus to the samples did not increase the level of antinutrients in the formulated diets. The level of antinutrients was very low and cannot hinder nutrient bioavailability in the enriched complementary foods.

\subsection{Micronutrient Bioavailability in the Marcrotermes bellicosus-enriched Diets}

The significantly higher serum levels of iron, zinc, calcium and vitamin A in rats groups fed the control and experimental diets confirmed the contribution of M. bellicosus to serum micronutrients in the two experimental diet groups, implying that addition of $M$. bellicosus to complementary foods at $20 \%$ inclusion level will improve the bioavailability of iron, vitamin A, and zinc which are micronutrients of public health importance. Micronutrient requirements are high during the first 2 years of life to support the rapid growth and development during this period. Iron and zinc are among micronutrients whose daily requirements' are difficult to meet with plant-based complementary foods alone, hence, the need to obtain them from animal-source foods, or be fortified in some way (Dewey 2013). Micronutrients are essential for growth, development, and prevention of illness in young children (WHO, 2009). Adequate intakes of micronutrients, such as iron, zinc, and calcium, are important for ensuring optimal health, growth, and development of infants and young children (Caballero et al., 2005; Rolfes et al., 2009)

\subsection{Histopathological Assessment of Rat Internal Organs}

The result obtained for histopathological effects of feeding rats with the control and experimental diets revealed that the diets had no pathological alteration on the kidney morphology of rats in their groups. The result of the basal diet showed that inadequate/lack of protein intake for a period of time can have negative effect on kidney morphology and function. The kidney is an excretory organ that removes metabolised and nonmetabolised toxic materials from the body (Robbins et al., 1985); hence this organ would be exposed to high concentrations of the noxious materials that could have caused the lesions. This result has confirmed that M.bellicosus was not nephrotoxic to the kidney. While the basal diet showed slightly different hepatocyte arrangement with active macrophage action indicating slight insult on the liver; the diets enriched with M. bellicosus at $20 \%$ inclusion level and the control had no pathological lesions, demonstrating further that M. bellicosus is safe for consumption. The slight insult observed in the basal group may be due to absence of any protein source in their diet. The rats' spleen fed with the control and experimental diets had no histopathological changes, and also showed normal arrangement of the lymphocytes with the branching pattern of the veins. Also, normal red to white pulp ratio was observed after the feeding trial. This further confirmed that both control and experimental diets if properly prepared will not encourage the growth of unpleasant bacteria when consumed.

\section{Conclusion and Recommendation}

The nutrient content of $M$. bellicosus improved the nutrient quality of rice and yam used as staple for complementary foods in Southwest Nigeria, its protein supported rats growth at the three levels of inclusion, especially at $20 \%$ inclusion level. The nutrients were bioavailable without pathological effects on kidney, liver and spleen of rats fed the diets, showing that $M$. bellicosus had no toxic effects on these organs. This discovery suggests that $M$. bellicosus may be a promising animal source of protein and essential micronutrients without any negative effects on the organs of humans. The use of this insect as a cheap source of protein, energy and essential micronutrients is therefore recommended for nursing mothers especially from rural communities as a means of reducing infants and young children malnutrition when in season.

\section{References}

ACC/SCN. (2004). 5th Report on the world nutrition situation, nutrition for improvement. Geneva: World Health Organization.

Adepoju, O. T (2016). Assessment of fatty Acid profile, Protein and micronutrient bioavailability of Winged Termites (Macroterme bellicosus) Using Albino Rats Mal J Nutr, 22(1), 153-161

Adepoju, O. T., \& Ajayi, K. (2016) Nutrient Composition and Adequacy of two Locally Formulated Winged Termite (Macrotermes bellicosus) Enriched Complementary Foods. Journal of Food Research, 5(4), 222-231

Adepoju, O. T., \& Daboh, O. O. (2013). Nutrient Composition of Cirina forda (West wood) enriched 
complementary foods. Annals of Nutri \& Metab, 63(1-2), 139-144. https://doi.org/10.1159/000353885

Adepoju, O. T., \& Omotayo, O. A. (2014). Nutrient composition and potential contribution of winged termites (Macroterme bellicosus) to micronutrient intake of Consumers. British J. Appl Sci \& Technol, 4(7), 1149-1158. https://doi.org/10.9734/BJAST/2014/4420

Afiukwa, J. N., Okereke, C., \& Odo, M. O. (2013). Evaluation of proximate and mineral contents of termite (Trinervitermesgerminatus) from Abakaliki and Ndiezeizzi, Ebonyi state, Nigeria.Am. J. Food. Nutr., 3(3), 98-104. https://doi.org/10.5251/ajfn.2013.3.3.98.104

Aggett, P. J., \& Comerford, J. G. (1995). Zinc and human health. Nutrition Reviews, 53, S16-S22

AOAC. (2005). International, Official Methods of Analysis, 18th ed., AOAC International, Arlington, Virginia, USA.

AOAC. (2006). Association of Official Analytical Chemists Official methods of analysis of AOAC $\left(19^{\text {th }}\right.$ edn $)$ International, Gaithersburg, MD. USA.

Ayatse, J. O., Eka, O. U., \& Ifon, E. T. (1985). Biological evaluation of the effects of roasting on the nutritive value of maize (Zea mays). Nig. J Nutr Sci, 6(2), 99-104.

Badau, M. H., Nkama, I., \& Ajalla, C. O. (2002). Physicochemical properties of various pearl millet cultivars grown in Northern Nigeria. International Journals of Food Properties, 5(1), 37-47. https://doi.org/10.1081/JFP-120015592

Brown, K., Dewey, K., \& Allen, L. (1998).Complementary feeding of young children in developing countries. A review of current scientific knowledge. Geneva, WHO.

Caballero, B., Allen, L., \& Prentice, A, (2005). Editors. Encyclopedia of Human Nutrition. 2nd ed. Oxford: Elsevier Academic Press.

Dewey, K. G. (2013). The challenge of meeting nutrient needs of infants and young children during the period of complementary feeding: an evolutionary perspective. J Nutr., 143, 2050-2054. https://doi.org/10.3945/jn.113.182527

FAO/WHO (1991). Protein Quality Evaluation: Report of the Joint FAO/WHO Expert Consultation, FAO Food and Nutrition Paper 51. Rome: FAO.

FAO/WHO. (1998). Carbohydrates in Human Nutrition: Report of a Joint FAO/WHO Expert Consultation, 14-18 April 1997, Rome. FAO Food and Nutrition Paper No. 66. Rome.

Fernandez, R. A., Vanderjagt, J. D., Williams, M., Huang, Y. S., Chuang, Lu-Fe., Millson, M., Andrew, R., Pastuszyn, A., \& Glew, H. R. (2002). Fatty acid, amino acid and trace element analysis of five weaning food from Jos, Nigeria. Plant Foods for Human Nutrition, 57, 257-274. https://doi.org/10.1023/A:1021899103662

Gibson, R. S., Ferguson, E. L., \& Lehrfeld, J. (1998). Complementary foods for infant feeding in developing countries: their nutrient adequacy and improvement. Eur J Clin Nutr., 52, 764-70. https://doi.org/10.1038/sj.ejen.1600645

Griffiths, D. W., \& Jones, D. I. H. (1977). Cellulase inhibition by tannins in the testa of field beans (Viciafaba). J. Sci. Food Agric., 28(11), 938-989. https://doi.org/10.1002/jsfa.2740281106

Hallberg, L., \& Rossander, L. (1984). Improvement of iron nutrition in developing countries. Comparison of adding meat, soy protein, ascorbic acid, citric acid and ferrous sulphate on iron absorption from a simple Latin American type of meal. American Journal of Clinical Nutrition, 39, 577-587.

Huis, A., Van Itterbeeck, J., Klunder, H., Mertens, E., Halloran, A., Muir, G., \& Vantomme, P. (2013). Edible insects: Future prospects for food and feed security. In: Food and Agriculture Organization of the United Nations (FAO) Forestry Paper, 171, 67-79

Ibeanu, V., \& Okeke, E. G. (2001). Development and acceptability test of amylase rich flour Itam EH, Eka OU Ifon ET. 1986 .Biological evaluation of the nutritive value of Africa walnut (Coula Edulis). Nigerian journal of Nutritional Science, 7(1), 9-12

Janet Hoff, LVT, RLATG. (2000). Methods of Blood Collection in the Mouse. Technique, 29(10).

Kikafunda, J. K., Walker, A. F., \& Tumwine, J. K. (2003). Weaning foods and practises in Central Uganda: A cross sectional study. Afr. J. Food Agric. Nutr. Devel., 3(2), 1-13. 
Kinyuru, J. N., Konyole, S. O., Roos, N., Onyango, C. A., Owino, V. O. ... Kenji, G. M. (2013). Nutrient composition of four species of winged termites consumed in western Kenya. J. Food Comp. Anal. 30, 120-124. https://doi.org/10.1016/j.jfca.2013.02.008

Lutter, C. K. (2003). Macro-level approaches to improve the availability of complementary foods. Food Nutr Bull, 24, 83-103. https://doi.org/10.1177/156482650302400105

Makkar, H. P., \& Becker, K. (1996). Nutritional value and antinutritional components of whole and ethanol extracted Moringaoleiferaleaves. Animal feed Sci Technol, 63, 211-238. https://doi.org/10.1016/S0377-8401(96)01023-1

Mitsuhashi, Jun. (1992). Edible insects of the world. Tokyo, Japan, Kokinshoin. 18-51.

NDHS (2013) Nigeria Demographic and Health Survey https://www.ncbi.nlm.nih.gov/pubmed/982951(Accessed on 12 June, 2017).

Ogunlade, I, Olaifa, O., Olukemi, A., Adeniran, O. A., \& Ogunlade, A. O. (2011). Effect of domestic processing on the amino acid profile of Dioscorea rotundata (White yam). African Journal of Food Science, 5(1), 36.

Okafor, J. N. C., Ozumba, A. U., Onu, L. I., Daodu, A. N., \& Olatunji. O. O. (2008). Chemical microbial and sensory properties of properties of weaning foods from blend of Nigerian food stuff. Journal International Research Technology, 2, 31-36.

Onofiok, N. O., \& Nnanyelugo, D. O. (1998). Weaning foods in West Africa: nutritional problems and possible solutions. FoodNutrBull, 19(1), 27-33. https://doi.org/10.1177/156482659801900105

Robbins, S. L., Cotran, R. S., \& Kumar, V., eds. (1984). Environmental Pathology. Chemical and Drug Injury. In: Pathological Basis of Disease. 3rd edition, W.B. Saunders and Company, Philadelphia, 452-480.

Rolfes, S. R., Pinna, K., \& Whitney, E. (2009).Understanding normal and clinical nutrition. Eighth Edn Wadsworth Cengage Learning.; 421-423, 455.

Roth, A. R., \& Townsend, C. E. (2003). Nutrition and diet therapy, 8th edn. Delmar Learning, Thomson Learning Inc Canada. 150-153.

Sarika, Chaturvedi, Joanna, Raven, \& Bhushan, Patwardhan, (2017). Addressing child under nutrition: can traditional practices offer a solution?, Global Health Action, 10(1), 1327255. https://doi.org/10.1080/16549716.2017.1327255

Sehmi, J. K., (1993). National Food Composition Tables and the Planning of Satisfactory Diets in Kenya. Government Printers, Nairobi.

Solomon, M. (2005) Nutritive value of three potential complementary foods based on cereals and legumes.African J. Food, Agric., Nutr. \&Devpt (AJFAND), 5, 1-14.

Sudarmadji, S., \& Markakis, P. (1977).The phytate and phytase of soybean Tempeh.J. Sci. Food Agric., 28(4), 381-383. https://doi.org/10.1002/jsfa.2740280410

Walker, T. S., \& Ryan, J. G. (1990). Village and household economics in India's semi-arid tropics of Baltimore The Johns Hopkins pt/hlisIwr London

WHO, (2009). Recommendations on wheat and maize flour fortification. Meeting Report: Interim Consensus Statement. Geneva, World Health Organization. http://www.who.int/nutrition/publications/micronutrients/wheat_maize_fort.pdf, accessed

Williams, P. (2007). Nutritional composition of red meat. Nutrition and Dietetics, 64(4), 113-119. https://doi.org/10.1111/j.1747-0080.2007.00197.x

World Health Organization. (1998). Evidence for the ten steps to successful breastfeeding. Geneva: World Health Organization.

Yeung, D. L. (1998). Iron and micro nutrients complementary food fortification. Food Nutr. Bull., 19, 2. https://doi.org/10.1177/156482659801900211

\section{Copyrights}

Copyright for this article is retained by the author(s), with first publication rights granted to the journal.

This is an open-access article distributed under the terms and conditions of the Creative Commons Attribution license (http://creativecommons.org/licenses/by/4.0/). 